\title{
Diving behaviour of adult male white whales (Delphinapterus leucas) in Svalbard, Norway
}

\author{
Jade Vacquié-Garcia, Christian Lydersen \& Kit M. Kovacs \\ Norwegian Polar Institute, Fram Centre, Tromsø, Norway
}

\begin{abstract}
White whales (Delphinapterus leucas) in Svalbard remain near the coast much of the year, spending most of their time in front of tidewater glaciers. In this article, the diving behaviour of adult male white whales in Svalbard $(N=16)$ is presented based on satellite-relay data loggers that record time and depth of diving as well as positions. The loggers transmitted data for an average of $87 \pm 52$ days (range 2-163 days). After filtering, 55359 dives were available for the study. Most of the dives were extremely shallow (13 \pm $26 \mathrm{~m}$, maximum $350 \mathrm{~m}$ ) and of short duration $(97 \pm 123 \mathrm{~s}$, maximum $31.4 \mathrm{~min})$. At tidewater glacier fronts, the white whales optimized their time at the bottom of dives and spent longer periods resting at the surface after dives, in accordance with what would be expected when foraging. This behaviour was also documented when animals were out in the fjords. When the whales moved between areas around the archipelago, they swam close to the coast, staying right below the surface most of the time, presumably to minimize energy expenditure during transits. When sea ice formed during the winter, the whales were forced offshore into somewhat deeper areas with drifting ice. In these areas, the whales minimized time at the surface and dove somewhat deeper, sometimes reaching the bottom, presumably to feed on neritic prey.
\end{abstract}

\section{Introduction}

White whales (Delphinapterus leucas) are ice-associated Arctic endemic cetaceans that have a circumpolar distribution. Globally, there are around 200000 individuals occurring in approximately 20 stocks (Lowry et al. 2017). Since the early 1990s, movement patterns of white whales have been studied in various parts of the Arctic using satellite telemetry (Martin et al. 1993; Smith \& Martin 1994; Richard et al. 1997; Richard et al. 1998; Lydersen et al. 2001; Richard et al. 2001; Reeves et al. 2014; Hauser et al. 2017). Highly variable movement patterns have been described, with some stocks undertaking large-scale annual migrations between summering and wintering sites (Richard et al. 2001), while others remain in the same area year-round, shifting offshore only when excluded from coastal habitat by land-fast sea ice formation (e.g., Moore et al. 2000; Watt et al. 2016). The diving behaviour of white whales has also been studied in many places in the Arctic and, similar to movement patterns, differs markedly among the various white whale stocks

\section{Keywords}

Arctic; beluga; climate change; environmental change; foraging; travelling

\section{Correspondence}

Kit M. Kovacs, Norwegian Polar Institute, Fram Centre, 9296 Tromsø, P.O. Box 6606 Langnes, Norway.E-mail:kit.kovacs@npolar.no

\section{Abbreviations: \\ AIC: Akaike Information Criterion Bt: bottom time (duration in seconds) Dmax: maximum depth recorded for a given dive (in metres) Dt: dive time (duration in seconds) residual Bt_DDt: residual of the relationship between the bottom duration and both the maximum depth and the dive duration SD: standard deviation \\ SE: standard error \\ SRDL: satellite-relay data logger St: surface time (duration in seconds), i.e., time spent at the surface between dives}


year-round (Lydersen et al. 2001; Vacquié-Garcia et al. 2018). In summer and autumn, Svalbard's white whales remain in largely ice-free areas (Lydersen et al. 2001; Vacquié-Garcia et al. 2018). The whales spend most of their time in front of the numerous tidewater glaciers of the archipelago (Lydersen et al. 2001; Błaszczyk et al. 2009; Vacquié-Garcia et al. 2018). These glacier fronts are known to be hotspots for foraging for seabirds and seals (Lydersen et al. 2014) and are thought to be the main foraging areas for white whales in Svalbard (Lydersen et al. 2001; Vacquié-Garcia et al. 2018). Fatty acid analyses of the blubber of white whales from this area suggest that polar cod (Boreogadus saida) and capelin (Mallotus villosus), two species particularly common in the cold high-productivity glacial front areas, were the main components of the diet of white whales in the late 1990s (Dahl et al. 2000). When sea ice forms in winter, the white whales are forced offshore, but generally remain close to Svalbard, in areas with drifting sea ice with concentrations of up to $90 \%$ (Lydersen et al. 2001; Lydersen et al. 2002; Vacquié-Garcia et al. 2018). Since 2010, white whales in Svalbard have spent more time offshore within fjords, which had not been documented previously, concomitantly decreasing their time in front of glaciers (Vacquié-Garcia et al. 2018; Hamilton et al. 2019). This shift in behaviour may be linked to the increased influxes of Atlantic water into the west coast fjords of Svalbard (Cottier et al. 2007; Spielhagen et al. 2011; Berge et al. 2015). This warm, salty water brings with it Atlantic prey species, which the whales could be targeting. When the whales from this stock move from one foraging area to another, they do so in a directed, rapid manner, swimming very close to the shoreline, hence remaining in shallow water most of the time (Lydersen et al. 2001; Vacquié-Garcia et al. 2018).

Although the movement patterns of Svalbard white whales are relatively well-documented, nothing is known about their diving behaviour. Understanding the behaviour of diving animals when they are below the water surface is essential to better assess their foraging behaviour and habitat use (Croxall et al. 1985; Martin et al. 1998; Fedak et al. 2001; Thums et al. 2008). The aim of the present study was therefore to document the diving behaviour of these whales in the Svalbard area and to investigate whether their behaviour differs in relation to the various habitats they occupy.

\section{Methods}

\section{Data logger deployments and data collection}

White whales were captured in several fjords in Spitsbergen, the largest island within the Svalbard
Archipelago, Norway, during the summers of 2013-16 (see Vacquié-Garcia et al. 2008 for capture methodology, locations, etc.). Adult animals (white skin colour) were instrumented (see Vacquié-Garcia et al. 2018 for more details) with SRDLs (Sea Mammal Research Unit, University of St Andrews) specially designed to fit on the dorsal ridge. Transmitters were deployed on a total of 16 males and two females. Because of the small sample size for females and the fact that they are often observed in segregated groups that are likely to behave very differently than all-male groups (O'Corry-Crowe 2018), this study reports only on males.

The SRDLs deployed on white whales in this study collect and transmit information on their location and their diving behaviour via the Argos satellite system (for details see Fedak et al. 2002 and Boehme et al. 2009). Locations are estimated by the orbiting satellites and a Location Class $(\mathrm{Z} / \mathrm{B} / \mathrm{A} / \mathrm{1} / 2 / 3)$, associated with an error (Location Class 3 is the highest accuracy), is assigned to each position (Fedak et al. 2002; Lowther et al. 2015). The full-resolution profiles of dives are compressed on-board, resulting in four at-depth points in addition to two surface points (start and end) for each dive. A randomly selected subset of these compressed timedepth profiles is transmitted from each six-hour period with the corresponding Dt, Dmax and St (Fedak et al. 2002).

\section{Data processing}

Track filtration. All data processing and modelling were done using the $\mathrm{R}$ statistical framework ( $\mathrm{R}$ Development Core Team 2010). Satellite-derived locations were first filtered using a speed, distance and angle filter (Freitas et al. 2008) using the $\mathrm{R}$ package argosfilter (http:// cran.r-project.org). The swimming speed threshold was set at $3 \mathrm{~m} / \mathrm{s}$ and all spikes with angles smaller than 15 and 25 degrees were removed if their extension was greater than 2500 or $5000 \mathrm{~m}$, respectively (Richard et al. 1998).

Because white whales in the Svalbard area are extremely coastal (see Lydersen et al. 2001; Vacquié-Garcia et al. 2018), locations were further processed using a simplified particle filter correcting for on-land positions (for details on the standard particle filter, see Tremblay et al. 2009). Each filtered location was first classified as an at-sea or on-land location using a land/glacier mask for Svalbard from 2015 (Norwegian Polar Institute, www.npolar.no) (see Vacquié-Garcia et al. 2018). Fifty possible locations (i.e., particles [Tremblay et al. 2009]) were then created for each on-land location, within a radius based on each point's Argos error. Argos errors used for the various Location Classes were taken from Lowther et al. (2015). Each of the created particles was 
then classified as at-sea or on-land. Finally, each original on-land location was corrected based on the geographic average of all of its at-sea particles. Location estimates that remained on land after the correction were removed.

Dive filtration. Dives were analysed based on timedepth inflection points, selected by a broken-stick model (see Fedak et al. 2002; Fedak et al. 2001) along with start and end points. Dt was defined as the period of time spent under water below a threshold of $1.5 \mathrm{~m}$ for a duration of more than $8 \mathrm{~s}$ (i.e., the default parameterization of the tags for shallow divers [Fedak et al. 2002]). St was defined as the period between dives during which animals stayed at depths between 0 and $1.5 \mathrm{~m}$. Descent and ascent rates $(\mathrm{m} / \mathrm{s})$ were calculated for each dive as the ratio between the difference in depth and the difference in time between the start point and the first time-depth point of the dive and between the last time-depth point and the end point of the dive, respectively. Outliers with ascent or descent rates higher than $5 \mathrm{~m} / \mathrm{s}$ were removed prior to analyses. Locations of retained dives were estimated by linear interpolation along the filtered and corrected tracks; dives along the tracks that occurred on land were removed.

Determination of spatial and diving metrics. Two spatial metrics were calculated for each dive, distance to the nearest coastline $(\mathrm{km})$ and distance to the nearest glacier front $(\mathrm{km})$. These distances were calculated using the land/glacier shapefile described previously and were used to distinguish between different habitats. If the distance to the nearest glacier front was less than $5 \mathrm{~km}$, the dive was assigned to the Glacier-Fronts habitat class. If the distance to the nearest glacier front was more than $5 \mathrm{~km}$ and the dive was inside a fjord, the dive was assigned to the Fjords habitat class. If the distance to the coast was less than $5 \mathrm{~km}$ and the dive was not already assigned to any one of the two habitat classes above, the dive was assigned to the Coastal habitat class. Finally, the remaining dives were assigned to the At-Sea habitat class. The $5 \mathrm{~km}$ threshold was chosen to take into account the Argos error and the land/glacier mapping inaccuracies.

In addition to the three dive metrics provided by the SRDLs directly (Dt, St and Dmax), Bt, which was estimated for each dive as the time spent at a depth exceeding $80 \%$ of Dmax, was also analysed (see Carbone $\delta$ Houston 1996; Lesage et al. 1999).

\section{Analysis and the modelling approach}

The three dive metrics given by the SRDLs were analysed independently as a function of the habitat classes using linear mixed-effect models (lme function in the
$\mathrm{R}$ package lme4). To explore possible diel patterns, a day (between 08:00 and 20:00) versus night (between 20:01 and 07:59) variable was added to the models. Individual identification number was included as a random effect in the models. Temporal autocorrelation was explored, but had no influence, so it was not included in the final models presented. Models were fitted with a Gaussian family distribution and all the response metrics were log transformed to meet model assumptions. Null response variable values were excluded. Model selection took place using AIC as recommended by Zuur et al. (2009) and a Tukey multiple comparison procedure was used to compare between each pair of habitat classes (glht function in the $\mathrm{R}$ package multcomp; significance was fixed at $p \leq 0.05)$.

Transit times to and from the bottom are generally longer for deep dives compared to shallow dives-the amount of time that can be spent at the bottom (or the effective Dt), within the animal's physiological constraints, is shorter for deep dives (Bailleul et al. 2008). In order to account for the effects of Dmax and Dt on Bt, a multiple regression was fitted between Dmax, Dt and Bt (see Bailleul et al. 2008). Because all the study animals were large, adult males, potential influences of body mass and length were not explored. A linear mixed-effect model (lme function in the R package lme4) was used to run this multiple regression; individual identification number was included as a random effect. This model was also fitted with a Gaussian family distribution, and the Bt was log transformed before modelling to meet model assumptions. Residual Bt_DDts (i.e., Bt in relation to Dmax and Dt) were then extracted. Positive residuals indicate dives with a longer Bt than average for a given Dmax and Dt, suggesting an increase in the diving effort, while negative residuals indicate a shorter Bt than average, which suggests a decrease in the diving effort. The residuals were then investigated in relation to habitat class using linear mixed-effect models with individual identification number included as a random effect. Model selection took place using AIC as recommended by Zuur et al. (2009) and a Tukey multiple comparison procedure was used to compare between each pair of habitats (glht function in the R package multcomp; significance was fixed at $p \leq 0.05$ ).

To explore how the animals used the water column in the various habitats, Dmax, the ratio between Dmax and the bathymetry (i.e., ratio depth-bathymetry) and residual Bt_DDt was explored according to the habitat type. Bathymetry was extracted from the International Bathymetric Chart of the Arctic Ocean version 3.0 (Jakobsson et al. 2012). In order to take into account the Argos error and the error in the filtration /correction of the tracks in the very coastal environment used by white whales in Svalbard, the mean bathymetry (i.e., mean bottom depth 
[m]) was calculated to describe the bathymetry in the area around the dives, rather than extracting only the bathymetry at the point-location where the dive occurred. This was assessed using a particle approach, similar to the one described above, in which 50 particles were created for each dive in a $5 \mathrm{~km}$ radius and a mean was calculated. To facilitate this analysis, the maximum value of the ratio depth-bathymetry variable was fixed at 1 . To avoid collinearity problems between the variables, a principal component analysis was conducted first and then a mixed classification method was subsequently applied on the three resulting principal components (Lebart et al. 1997) based both on a k-means and a hierarchical clustering analysis. The k-means step partitioned observations into $\mathrm{k}$ clusters ( $\mathrm{k}$ was arbitrarily fixed at 20). The 20 clusters were then classified hierarchically into groups according to the distances between them using the average linkage clustering method (hclus function in the $\mathrm{R}$ package stats). Statistically different groups corresponded to separate types of dives in a given habitat class.

\section{Results}

The SRDLs deployed on the 16 adult male white whales in this study provided location data for an average of $87 \pm 52$ days (range 2-163 days; movement and tagging

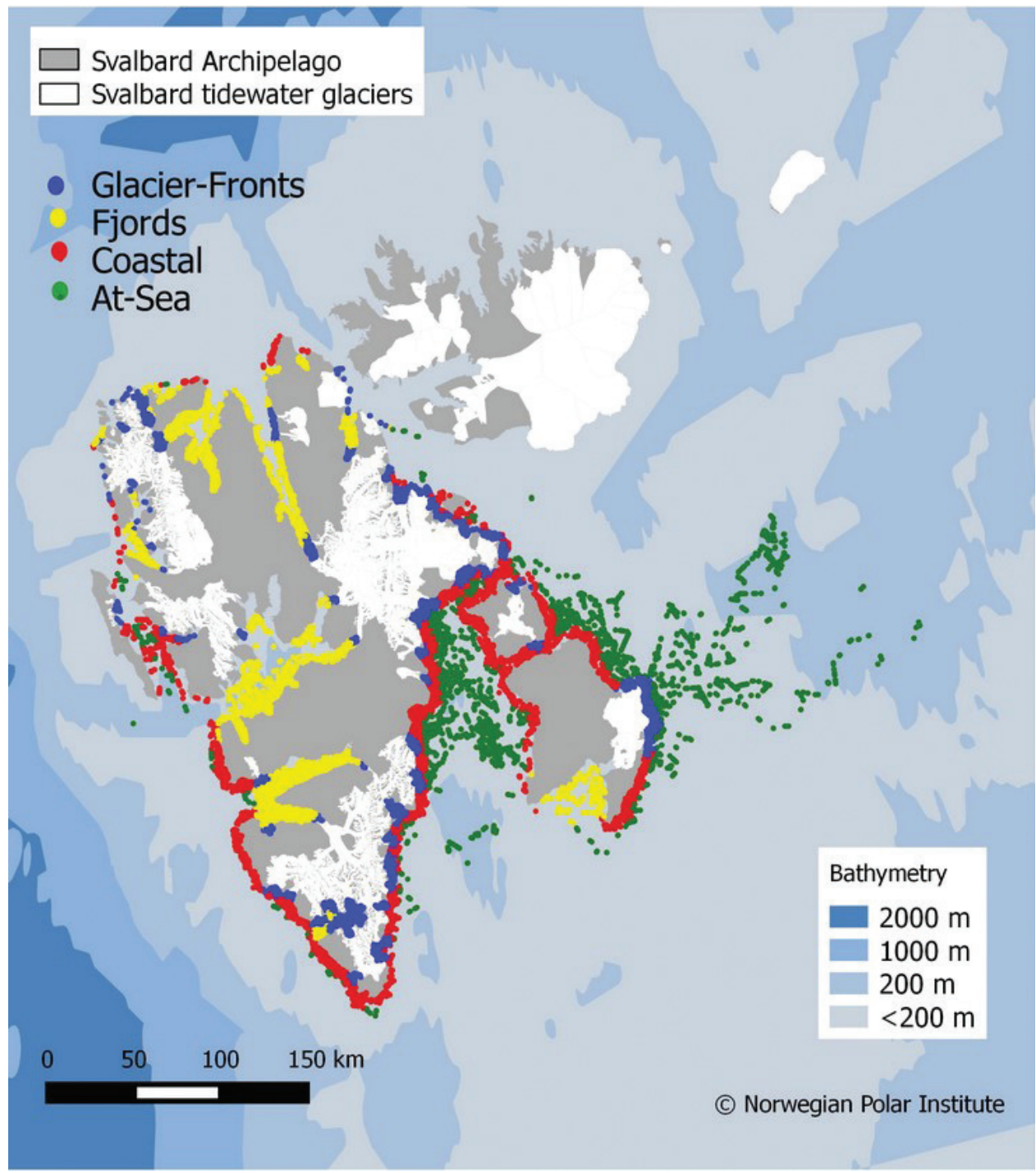

Fig. 1 Dive locations for white whales in Svalbard, Norway, plotted according to habitat classes. Interpolated locations for the dives of the 16 adult male white whales equipped with SRDLs devices in Svalbard, Norway (2013-16) after filtration and correction of their tracks, plotted according to their occurrence in the four different habitat classes. Bathymetry lines come from www.naturalearthdata.com. 
locations shown in Fig. 1b by Vacquié-Garcia et al. 2018). A total of 64400 dives were reported by the SRDLs. Filtering processes removed 9041 (14\%) dives, leaving 55359 (86\%) dives for analyses (Fig. 1, Table 1).

Average Dmax was $13 \pm 26 \mathrm{~m}$, with the deepest dive recorded being $350 \mathrm{~m}$. However, most dives (62\%) were shallower than $5 \mathrm{~m}$ (Fig. 2). Average Dt was $97 \pm 123 \mathrm{~s}$ (range: $8 \mathrm{~s}-31.4 \mathrm{~min}$ ) and average St was $62 \pm 72 \mathrm{~s}$ (range: $0 \mathrm{~s}-9.3 \mathrm{~min}$ ) (Fig. 2). Average Bt (available for 91\% of the dives) was $54 \pm 77 \mathrm{~s}$ (range: $1 \mathrm{~s}-28.3 \mathrm{~min}$ ). Thirty-six per cent $(N=20093)$ of the dives occurred in the Glacier-Fronts habitat class, $26.3 \%(N=14543)$ in Fjords, $26.3 \%(N=14563)$ in Coastal and $11.1 \%(N=6160)$ in the At-Sea habitat class (Fig. 1, Table 1).

No diel patterns were found regarding the diving behaviour of white whales in the Svalbard area; however, differences in behaviour did occur between different habitats. Diving was deepest in the At-Sea habitat class, followed by the Glacier-Fronts, then the Fjords and finally the Coastal habitat class (Tables 2, 3). Dt was significantly longer in the At-sea and Glacier-Fronts habitat classes compared with the other two habitats and Dt was significantly longer in the Fjords class compared with the Coastal habitat class (Tables 2, 3). St was significantly longer in the Glacier-Fronts and Fjords habitat classes compared with the other habitat classes, and St was significantly longer in the At-Sea class than in the Coastal habitat class (Tables 2, 3).

Bt was positively related to both Dt (slope: 0.01; $p<0.001$ ) and Dmax (slope: 0.018; $p<0.001$ ).
The interaction between the Dt and the Dmax was also significant (with negative slope: $-0.00006 ; p<0.001$ ). The analysis of the residuals extracted from this relationship showed significant differences between the various habitat classes, with an exception of Fjords and Coastal habitat classes which were similar (Table 3). Residual Bt_DDt was the greatest in the Fjords and Coastal habitat classes, followed by the Glacier-Fronts and the At-Sea habitat classes.

Variability in bathymetry from the shoreline out into the fjords was so high over very short distances that Argos errors around locations made it impossible to explore where in the water column the whales spent time in these habitats. In the case of the Glacier-Fronts habitat class, data on bathymetry do not exist near the front. In addition, as for the Fjords and Coastal habitats, the variability in bathymetry as one moves away from the fronts was so high that analyses regarding the bathymetry were not possible for the Glacier-Fronts habitat either. In contrast, bathymetric maps are available for the At-Sea habitat class and depth does not vary dramatically over short distances (the average was $2 \mathrm{~m}$ of variability in a $5 \mathrm{~km}$ radius around each At-Sea dive); it was therefore possible to explore Dmax versus bathymetry. When At-Sea (for dives where bottom duration could be calculated, $N=5766$ ), increasing Dmax (and depth-bathymetry ratios) corresponded to increased residual Bt_DDt (Fig. 3). The mixed classification method identified two different types of dives in this habitat (Fig. 4). The first dive type (Type 1 hereafter; $99 \%$ of the dives in the

Table 1 White whales tagging metrics. Metrics for 16 adult male white whales equipped with biotelemetry devices in Svalbard, Norway, including tagging date, tagging location, tracking duration and number of dives per habitat class.

\begin{tabular}{|c|c|c|c|c|c|c|c|c|}
\hline ID no. & $\begin{array}{l}\text { Tagging } \\
\text { date }\end{array}$ & $\begin{array}{l}\text { Tagging } \\
\text { location }\end{array}$ & $\begin{array}{c}\text { Tracking } \\
\text { duration (days) }\end{array}$ & $\begin{array}{l}\text { Total number } \\
\text { of dives }\end{array}$ & $\begin{array}{c}\text { Glacier-Fronts } \\
\text { dives }\end{array}$ & $\begin{array}{l}\text { Fjords } \\
\text { dives }\end{array}$ & $\begin{array}{l}\text { Coastal } \\
\text { dives }\end{array}$ & $\begin{array}{l}\text { At-Sea } \\
\text { dives }\end{array}$ \\
\hline 2013-1 & 16.08 .2013 & $79.78-12.16$ & 142 & 8532 & 2078 & 2984 & 2682 & 788 \\
\hline 2013-2 & 23.08 .2013 & $78.41-17.27$ & 96 & 2255 & 565 & 1164 & 496 & 30 \\
\hline $2013-3$ & 23.08.2013 & 78.33-15.71 & 82 & 1656 & 751 & 420 & 442 & 43 \\
\hline $2014-8$ & 18.08.2014 & $77.49-14.66$ & 21 & 1690 & 173 & 1342 & 175 & 0 \\
\hline 2014-2 & 14.08 .2014 & $76.98-16.37$ & 51 & 1779 & 855 & 3 & 504 & 417 \\
\hline 2014-5 & 11.08 .2014 & $76.98-16.37$ & 126 & 6899 & 3071 & 999 & 1259 & 1570 \\
\hline 2014-1 & 11.08 .2014 & $76.98-16.37$ & 20 & 792 & 142 & 361 & 232 & 57 \\
\hline 2014-4 & 03.08 .2014 & $78.53-18.87$ & 118 & 2074 & 1225 & 0 & 670 & 179 \\
\hline $2015-5$ & 19.07.2015 & 79.32-11.72 & 19 & 1186 & 217 & 607 & 263 & 99 \\
\hline $2015-8$ & 19.07.2015 & 79.15-11.6 & 2 & 136 & 31 & 69 & 36 & 0 \\
\hline $2016-3$ & 09.08 .2016 & $78.04-14.22$ & 163 & 4733 & 1429 & 1727 & 960 & 617 \\
\hline $2016-4$ & 19.07.2016 & $78.45-11.68$ & 56 & 3307 & 791 & 893 & 1498 & 125 \\
\hline $2016-2$ & 04.08 .2016 & $78.05-14.01$ & 115 & 3467 & 1695 & 1173 & 521 & 78 \\
\hline 2016-1 & 14.08 .2016 & $78.38-17.03$ & 146 & 6744 & 2967 & 1602 & 1938 & 37 \\
\hline
\end{tabular}



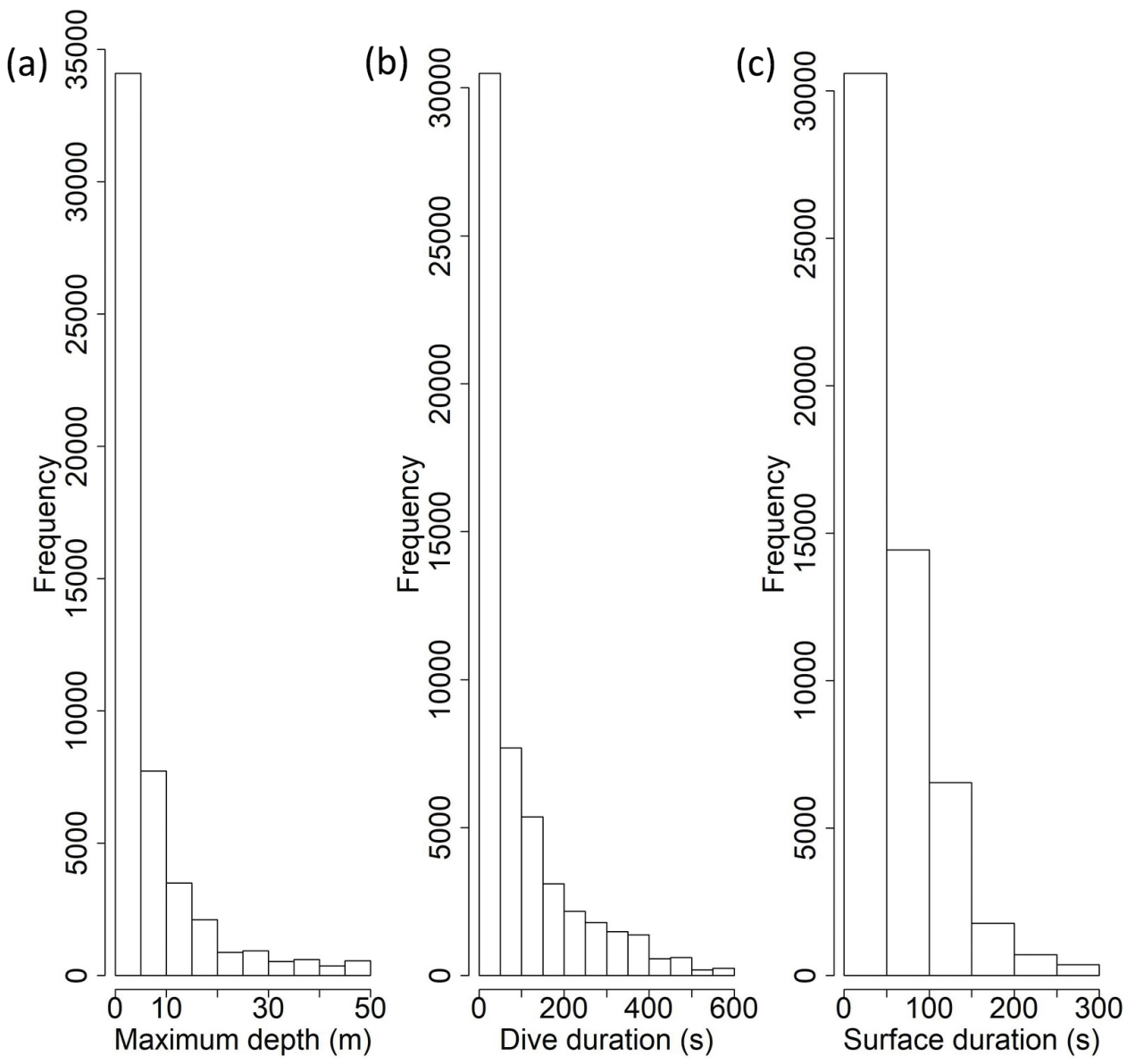

Fig. 2 Frequency distributions for (a) Dmax, (b) Dt and (c) St.

Table 2 Diving metrics for adult male white whales studied in Svalbard, Norway, according to habitat class.

\begin{tabular}{|c|c|c|c|c|c|c|}
\hline \multirow[t]{2}{*}{ Habitat classes } & Dmax & Range & $\mathrm{Dt}$ & Range & St & Range \\
\hline & Mean \pm SD & & Mean \pm SD & & Mean \pm SD & \\
\hline Fjords & $13.9 \pm 27.2$ & $1.5-350.0$ & $92.5 \pm 117.1$ & $8.0-1628.0$ & $67.2 \pm 76.2$ & $0.0-555.0$ \\
\hline Coastal & $7.6 \pm 14.8$ & $1.5-330.0$ & $76.4 \pm 103.4$ & $8.0-988.0$ & $55.8 \pm 72.2$ & $0.0-555.0$ \\
\hline At-Sea & $19.6 \pm 35.1$ & 1.5-320.0 & $122.8 \pm 147.0$ & $8.0-1116.0$ & $57.1 \pm 63.5$ & $0.0-555.0$ \\
\hline
\end{tabular}

Table 3 Tukey multiple test procedure comparing Dmax, Dt, St and residual Bt_DDt of the dives from white whales tracked in Svalbard according to the habitat class.

\begin{tabular}{|c|c|c|c|c|c|c|c|c|c|c|c|c|}
\hline \multirow[t]{2}{*}{ Pairs of habitat classes } & \multicolumn{3}{|c|}{ Dmax } & \multicolumn{3}{|c|}{ Dt } & \multicolumn{3}{|c|}{ St } & \multicolumn{3}{|c|}{ Residual Bt_DDt } \\
\hline & Estimate & SE & $p$ & Estimate & SE & $p$ & Estimate & SE & $p$ & Estimate & SE & $p$ \\
\hline Fjords/Coastal & 0.257 & 0.014 & $<0.001$ & 0.104 & 0.015 & $<0.001$ & 0.135 & 0.013 & $<0.001$ & 0.002 & 0.008 & 0.990 \\
\hline Glacier-Fronts/Coastal & 0.408 & 0.013 & $<0.001$ & 0.309 & 0.014 & $<0.001$ & 0.160 & 0.012 & $<0.001$ & -0.029 & 0.007 & $<0.001$ \\
\hline At-Sea/Coastal & 0.542 & 0.018 & $<0.001$ & 0.342 & 0.019 & $<0.001$ & 0.106 & 0.017 & $<0.001$ & -0.107 & 0.010 & $<0.001$ \\
\hline Glacier-Fronts/Fjords & 0.151 & 0.013 & $<0.001$ & 0.204 & 0.014 & $<0.001$ & 0.026 & 0.012 & 0.165 & -0.031 & 0.007 & $<0.001$ \\
\hline At-Sea/Fjords & 0.285 & 0.019 & $<0.001$ & 0.237 & 0.020 & $<0.001$ & -0.028 & 0.018 & 0.379 & -0.109 & 0.010 & $<0.001$ \\
\hline At Sea/Glacier-Fronts & 0.134 & 0.017 & $<0.001$ & 0.033 & 0.018 & 0.270 & -0.054 & 0.016 & 0.005 & -0.078 & 0.009 & $<0.001$ \\
\hline
\end{tabular}




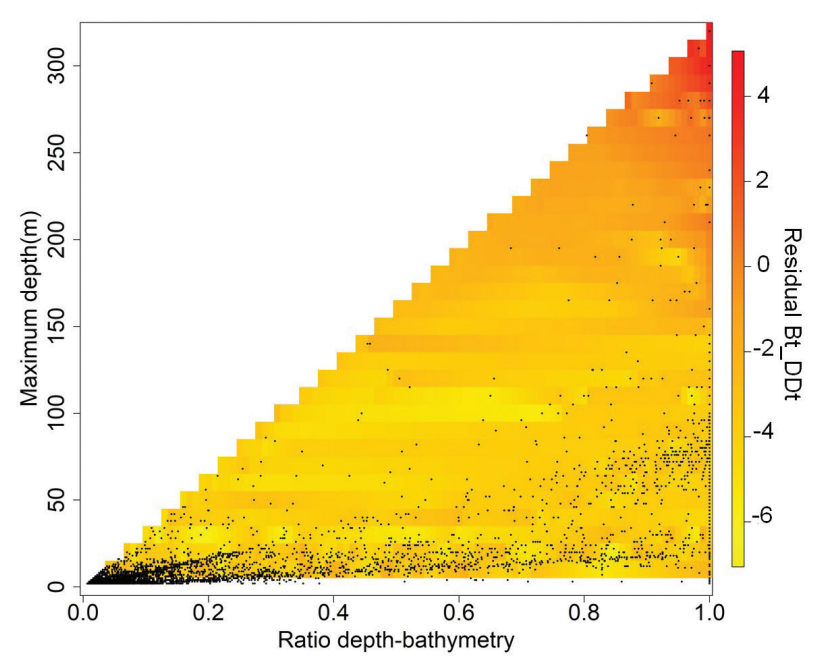

Fig. 3 Heat plot representing the relationship between Dmax, the ratio of depth-bathymetry and residual Bt_DDt for white whales in Svalbard, Norway, conducted in the At-Sea habitat class.
At-Sea habitat class) was characterized by low depthbathymetry ratios $(0.31 \pm 0.36)$ and shallow Dmax (18.86 $\pm 28.95 \mathrm{~m}$ ) (Fig. 4a, b); residual Bt_DDt for these dives was approximately $0(-0.10 \pm 0.62)$ (Fig. $4 \mathrm{c})$. The second dive type (Type 2 hereafter; $1 \%$ of the dives in the At-Sea habitat class) was characterized by a depth-bathymetry ratio of about $1(0.96 \pm 0.06)$, deep Dmax (252.45 \pm $37.41 \mathrm{~m}$ ) (Fig. 4a, b) and positive values for the residual Bt_DDt $(2.35 \pm 1.15)$ (Fig. 4c).

\section{Discussion}

Svalbard's white whales have a small distributional range, remain coastal through most of the year and show only limited seasonal movement patterns (Lydersen et al. 2001; Vacquié-Garcia et al. 2018). In this study, the diving behaviour of this stock has been found to be similarly conservative; dives are generally shallow and of short duration compared to white whales in other areas.
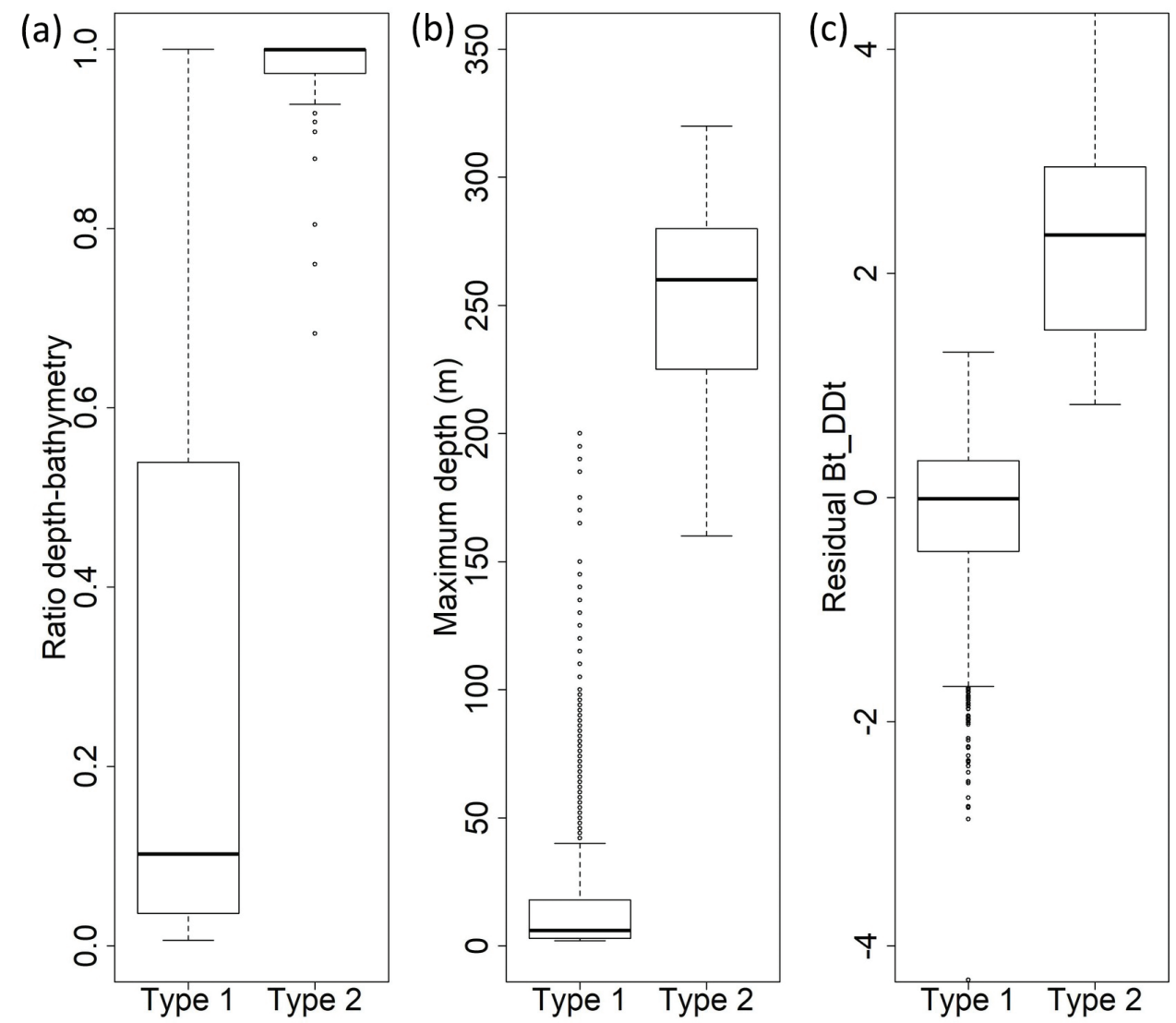

Fig. 4 Boxplot of (a) the ratio between depth and bathymetry for Type 1 and Type 2 dives, (b) Dmax according to dive type and (c) residual of Bt_DDt for the two dive types identified in the At-Sea habitat class (via mixed classification) for adult male white whales in Svalbard, Norway. 
Average Dmax for white whales in other localities are 40-50 m (Martin et al. 1998; Hauser et al. 2015; Watt et al. 2016). Some exceptions to this generality occur in summering areas, where white whales visit extremely shallow areas in Hudson Bay and the St Lawrence Estuary for short periods (Kingsley et al. 2001; Martin et al. 2001; Lemieux Lefebvre et al. 2018). However, shallow diving is the norm for Svalbard white whales: more than $60 \%$ of their dives are shallower than $5 \mathrm{~m}$, which is the surface threshold for most studies (e.g., Heide-Jørgensen et al. 1998; Heide-Jørgensen et al. 2001; Martin et al. 2001). In addition, white whales in other areas are known to perform deep diving, routinely up to 300-400 $\mathrm{m}$ and sometimes to $>900 \mathrm{~m}$ (Martin \& Smith 1992, 1999; Martin et al. 1993; Martin et al. 1998; Hauser et al. 2015), with average durations of more than $20 \mathrm{~min}$ (Heide-Jørgensen et al. 1998; Hauser et al. 2015). In Svalbard, only $0.5 \%$ of the dives were longer than $10 \mathrm{~min}$ and only $0.01 \%$ of dives exceeded $300 \mathrm{~m}$ (maximum depth was $350 \mathrm{~m}$ ). Most habitats occupied by the white whales in Svalbard are shallow, resulting in these limited diving metrics. However, even when white whales in Svalbard were pushed offshore into deeper water by winter ice formation, they still performed mostly shallow dives. It is important to note that these results are obtained using the definition of a dive as a submergence beyond $1.5 \mathrm{~m}$ for more than $8 \mathrm{~s}$. Most studies use a deeper dive threshold (e.g., Heide-Jørgensen et al. 1998; Heide-Jørgensen et al. 2001; Martin et al. 2001). It is also important to note that data from this study only represent part of the year (from summer to winter), so whether or not the animals continued their shallow diving behaviour during late winter and early spring, after the tags had stopped and before the animals returned inshore, is unknown. Finally, this study focussed only on males from this stock and further studies including females are essential to have a better understanding of the diving behaviour of the entire stock.

No diel patterns were found in the diving behaviour of the male white whales in Svalbard, but their behaviour did vary depending on the habitat they occupied, though the modest diving displayed in this stock limited the range of these differences. The Glacier-Fronts habitat was where the white whales spent most of their time in Svalbard (Vacquié-Garcia et al. 2018) and where they performed some of their deepest dives (Tables 2, 3). In this habitat, the animals had relatively long Bt (in relation to Dmax and Dt), followed by particularly long St (Tables 2, 3). This is a common pattern for air-breathing marine predators in areas where they are foraging, with quick transits through the water column, spending more time at the bottom of their dives where they encounter prey and more time at the surface following the dive to rest after foraging efforts (Mori et al. 1998). The diving performance of the white whales in Svalbard in the Glacier-Fronts habitat class is thus consistent with previous studies that suggested that tidewater glacier fronts were their main foraging areas (Dahl et al. 2000; Lydersen et al. 2001; Vacquié-Garcia et al. 2018).

When in the Fjords habitat, the whales dove shallower than in the Glacier-Fronts habitat, but they spent a lot of time at the bottom of their dives (relative to Dmax and Dt) compared to the other habitats and they had long St following dives in this habitat as well (Tables 2, 3). Diving behaviour in the Fjords habitat was possibly also associated with searching for food and feeding. This has been suggested by Vacquié-Garcia et al. (2018) and Hamilton et al. (2019), on the basis of twodimensional movement patterns in this habitat. During the last decade, Atlantic Water with higher temperatures than previously recorded in Svalbard (Spielhagen et al. 2011 ) has flooded into the fjords of west Spitsbergen. This has caused reduced ice formation and influxes of boreal fish and invertebrate species (Cottier et al. 2007; Spielhagen et al. 2011; Berge et al. 2015). Atlantic cod (Gadus morhua), haddock (Melanogrammus aeglefinus) and herring (Clupea harengus) have recently replaced native Arctic fish to a large degree; in particular, polar cod has declined in the region (Fossheim et al. 2015). As a result, diets of some seabirds and marine mammals in the Svalbard area have already changed to include more Atlantic and less Arctic prey (Descamps et al. 2017; Vihtakari et al. 2018). The white whales might also be accepting these new species, which are not affiliated with glaciers, as prey, but dietary analysis should be conducted to confirm this suspicion.

The whales had the shortest and the shallowest dives in the Coastal habitat class. During coastal dives, the whales spent a lot of time in the bottom phase of the dive, as much as in the Fjords habitat, but these dives were very shallow and the whales spent relatively short periods at the surface between dives compared to other habitats (Tables 2, 3). This type of transit diving, moving right below the surface (on average $7 \mathrm{~m}$ below the surface), reduces drag and energy expenditure during swimming, maximizing the efficiency of travelling (Hertel 1966; Fish 1996; Hindle et al. 2010). Feeding is therefore likely not occurring during these shallow coastal dives.

In the At-Sea habitat, the white whales did their deepest and longest dives (Tables 2, 3). However, they stayed the shortest relative amount of time at the bottom of the dives (Table 3). This is the wintering habitat for white whales in Svalbard, occupied when sea ice forces the animals offshore (Vacquié-Garcia et al. 2018). The relatively dense pack-ice, which they occupied in 
these offshore areas, likely provides several advantages, including shelter from surface or open-water predators and from inclement weather (Stirling 1997; Heide-Jørgensen \& Laidre 2004; Kovacs et al. 2011). However, if ice cover gets too dense, with too few cracks to breathe in, the risk of both entrapment and predation by polar bears (Ursus maritimus) increases (Smith 1985; Laidre $\delta$ Heide-Jørgensen 2005; Laidre et al. 2012), which could explain why the $\mathrm{St}$ in this habitat is short compared to the St in other habitats, especially in the Glacier-Fronts and Fjords habitat classes.

In Coastal, Fjords and Glacier-Fronts habitats, the extreme variation in bathymetry close to shore, combined with Argos error, precluded any sensible analyses regarding where in the water column the whales spent their time. In addition, for the Glacier-Fronts habitat, fronts are moving very quickly and in-depth information at the fronts is generally lacking on account of the risks associated with taking conventional measurements in areas with high calving activity. The At-Sea habitat class was hence the only one class where such analyses were possible with reasonably consistent bathymetry at a small scale around location points estimated for dives. Two different types of dives were identified in this habitat using a mixed classification method to investigate the relationship between bathymetry and the diving behaviour. Type 1 dives were quite shallow, that is, high in the water column. Residual Bt_DDt for these dives was close to 0 , which means that the animals stayed for a "normal" amount of time at the bottom of the dives, considering the others diving metrics; these were likely transit dives. In contrast, Type 2 dives were relatively deep, and these dives were situated close to (or at) the seabed. In these deep dives, the white whales remained for a disproportionately longer period of time at the bottom of the dive compared to Dmax and Dt. Diving to the seabed and spending a long time at the bottom are both signs of foraging by white whales in other areas (Heide-Jørgensen et al. 1998; Martin et al. 1998; Martin \& Smith 1999; Martin et al. 2001; Hauser et al. 2015). It seems likely that the white whales were feeding on neritic prey during these dives in the At-Sea habitat.

\section{Conclusion}

White whales in the Svalbard Archipelago spend most of the year in coastal waters, where their diving is very shallow and of short duration compared to white whales in other areas. While no diel patterns were found, dive behaviour did vary with the habitat they occupied. When the animals were in front of tidewater glaciers, they optimized the time at the bottom of their dives with longer periods of resting at the surface, in accordance with what would be expected when foraging. This type of dive behaviour was also documented during some of the time that the animals spent in the Fjords habitat, suggesting that white whales in Svalbard also now forage within the fjords away from tidal glacier fronts. When the whales move from one foraging area to another, they do so along the coast, swimming close to the surface much of the time. Finally, when sea ice forms along the coast in the autumn/winter, the whales are forced to leave the shore and move into deeper areas with drifting ice where they minimize the time at the surface. This habitat also appears to represent a foraging area, with animals diving close to the seabed when At-Sea. This study is a further confirmation of the atypical behaviour of the Svalbard white whale stock in relation to other stocks of this species in the Arctic.

\section{Acknowledgements}

The authors thank M.A. Blanchet, G. Christensen, M.A. Fedak, C.D. Hamilton, M. Haupt, C. Hunter, K. Hylland, R.A. Ims, O. Isaksen, A. Lowther, C. Lund, E. Lydersen, J. Orr, R.A. Ølberg, V. Semenova, B. Severinsen, M. Tryland and G.D. Villanger for their help with fieldwork over the years.

\section{Disclosure statement}

No potential conflict of interest was reported by the authors.

\section{Funding}

This study was supported by funds from the Norwegian Polar Institute, the Norwegian Research Council (through the following projects: Centre for ICE-Whales; Tidewater Glacier Retreat Impact on Fjord Circulation and Ecosystems; and Glaciers as Arctic Ecosystem Refugia), the Norwegian Polar Institute's Centre for Ice, Climate and Ecosystems and the Fram Centre's Fjord and Coast Flagship programme.

\section{References}

Bailleul F., Lesage V., Power M., Doidge S.W. \& Hammill M.O. 2012. Migration phenology of beluga whales in a changing Arctic. Climate Research 53, 169-178, doi: 10.3354/cr01104.

Bailleul F., Pinaud D., Hindell M., Charrassin J.-B. \& Guinet C. 2008. Assessment of scale-dependent foraging behaviour in southern elephant seals incorporating the vertical dimension: a development of the First Passage 
Time method. Journal of Animal Ecology 77, 948-957, doi: $10.1111 / j .1365-2656.2008 .01407 . x$.

Berge J., Heggland K., Lonne O.J., Cottier F., Hop H., Gabrielsen G.W., Nottestad L. \& Misund O.A. 2015. First records of Atlantic mackerel (Scomber scombrus) from the Svalbard Archipelago, Norway, with possible explanations for the extension of its distribution. Arctic 68, 54-61, doi: 10.14430/arctic4455.

Błaszczyk M., Jania J.A. \& Hagen J.O. 2009. Tidewater glaciers of Svalbard: recent changes and estimates of calving fluxes. Polish Polar Research 30, 85-142.

Boehme L., Lovell P., Biuw M., Roquet F., Nicholson J., Thorpe S.E., Meredith M.P. \& Fedak M. 2009. Animal-borne CTD-satellite relay data loggers for real-time oceanographic data collection. Ocean Science 5, 685-695, doi: 10.5194/os-5-685-2009.

Carbone C. \& Houston A.I. 1996. The optimal allocation of time over the dive cycle: an approach based on aerobic and anaerobic respiration. Animal Behaviour 51, 1247-1255, doi: 10.1006/anbe.1996.0129.

Cottier F.R., Nilsen F., Inal M.E., Gerland S., Tverberg V. \& Svendsen H. 2007. Wintertime warming of an Arctic shelf in response to large-scale atmospheric circulation. Geophysical Research Letters 34, L10607, doi: 10.1029/2007GL029948.

Croxall J.P., Everson I., Kooyman G.L., Ricketts C. \& Davis R.W. 1985. Fur seal diving behavior in relation to vertical distribution of krill. Journal of Animal Ecology 54, 1-8, doi: $10.2307 / 4616$.

Dahl T.M., Lydersen C., Kovacs K.M., Falk-Petersen S., Sargent J., Gjertz I. \& Gulliksen B. 2000. Fatty acid composition of the blubber in white whales (Delphinapterus leucas). Polar Biology 23, 401-409, doi: 10.1007/s003000050461.

Descamps S., Aars J., Fuglei E., Kovacs K.M., Lydersen C., Pavlova O., Pedersen A.O., Ravolainen V. \& Strøm H. 2017. Climate change impacts on wildlife in a High Arctic Archipelago. Global Change Biology 23, 490-502, doi: 10.1111 /gcb.13381.

Fedak M.A., Lovell P. \& Grant S.M. 2001. Two approaches to compressing and interpreting time-depth information as collected by time-depth recorders and satellite-linked data recorders. Marine Mammal Science 17, 94-110, doi: 10.1111/ j.1748-7692.2001.tb00982.x.

Fedak M., Lovell P., McConnell B. \& Hunter C. 2002. Overcoming the constraints of long range telemetry from animals: getting more useful data from smaller packages. Integrative and Comparative Biology 42, 3-10, doi: 10.1093/icb/42.1.3.

Fish F.E. 1996. Transitions from drag-based to lift-based propulsion in mammalian swimming. American Zoologist 36, 628-641, doi: 10.1093/icb/36.6.628.

Fossheim M., Primicerio R., Johannesen E., Ingvaldsen R.B., Aschan M. \& Dolgov A.V. 2015. Recent warming leads to a rapid borealization of fish communities in the Arctic. Nature Climate Change 5, 673-677, doi: 10.1038/ NCLIMATE2647.

Freitas C., Lydersen C., Fedak M.A. \& Kovacs K.M. 2008. A simple new algorithm to filter marine mammal Argos locations. Marine Mammal Science 24, 315-325, doi: 10.1111/j.1748-7692.2007.00180.x.
Hamilton C., Vacquié-Garcia J., Kovacs K.M., Ims R.A., Kohler J. \& Lydersen C. 2019. Contrasting changes in space use induced by climate change in two Arctic marine mammal species. Biology Letters 15, article no. 20180834 doi: 10.1098/rsbl.2018.0834.

Hauser D.D.W., Laidre K.L., Parker-Stetter S.L., Horne J.K., Suydam R.S. \& Richard P.R. 2015. Regional diving behavior of Pacific Arctic beluga whales Delphinapterus leucas and possible associations with prey. Marine Ecology Progress Series 541, 245-264, doi: 10.3354/meps 11530.

Hauser D.D.W., Laidre K.L., Stern H.L., Moore S.E., Suydam R.S. \& Pichard P.R. 2017. Habitat selection by two beluga whale populations in the Chukchi and Beaufort seas. PLoS One 12(2), e0172755, doi: 10.1371/journal.pone.0172755.

Heide-Jørgensen M.P., Hammeken N., Dietz R., Orr J. \& Richard P.R. 2001. Surfacing times and dive rates for narwhals (Monodon monoceros) and belugas (Delphinapterus leucas). Arctic 51, 284-298, doi: 10.14430/arctic788.

Heide-Jørgensen M.P. \& Laidre K.L. 2004. Declining extent of open-water refugia for top predators in Baffin Bay and adjacent waters. Ambio 33, 487-494, doi: 10.1639/0044-7447(2004)033[0487:DEOORF]2.0.CO;2.

Heide-Jørgensen M.P., Richard P.R. \& Rosing-Asvid A. 1998. Dive patterns of belugas (Delphinapterus leucas) in waters near eastern Devon Island. Arctic 51, 17-26, doi: 10.14430/arcticl041.

Hertel H. 1966. Structure, form and movement. New York: Rheinhold.

Hindle A.G., Rosen D.A.S. \& Trites A.W. 2010. Swimming depth and ocean currents affect transit costs in Steller sea lions Eumetopias jubatus. Aquatic Biology 10, 139-148, doi: $10.3354 /$ ab00279.

Jakobsson M., Mayer L.A., Coakley B., Dowdeswell J.A., Forbes S., Fridman B., Hodnesdal H., Noormets R., Pedersen R., Rebesco M., Schenke H.W., Zarayskaya Y., Accettella D., Armstrong A., Anderson R.M., Bienhoff P., Camerlenghi A., Church I., Edwards M., Gardner J.V., Hall J.K., Hell B., Hestvik O.B., Kristoffersen Y., Marcussen C., Mohammad R., Mosher D., Nghiem S.V., Pedrosa M.T., Travaglini P.G. \& Weatherall P. 2012. The International Bathymetric Chart of the Arctic Ocean (IBCAO) version 3.0. Geophysical Research Letters 39, article no. L12609, doi: 10.1029/2012GL052219.

Kingsley M.C.S., Gosselin S. \& Sleno G.A. 2001. Movements and dive behaviour of belugas in northern Quebec. Arctic 54, 262-275, doi: 10.14430/arctic786.

Kovacs K.M., Moore S., Overland J.E. \& Lydersen C. 2011. Impacts of changing sea ice conditions on Arctic marine mammals. Marine Biodiversity 41, 181-194, doi: 10.1007/ s12526-010-0061-0.

Laidre K.L. \& Heide-Jørgensen M.P. 2005. Arctic sea ice trends and narwhal vulnerability. Biological Conservation 121, 509-517, doi: 10.1016/j.biocon.2004.06.003.

Laidre K.L., Heide-Jørgensen M.P., Stern H. \& Richard P. 2012. Unusual narwhal sea ice entrapments and delayed autumn freeze-up trends. Polar Biology 35, 149-154, doi: 10.1007/s00300-011-1036-8.

Lebart L., Morineau A. \& Piron M. 1997. Statistique exploratoire multidimensionnelle. (Multidimensional exploratory statistics.) 6th edn. Paris: Dunod. 
Lesage V., Hammill M.O. \& Kovacs K.M. 1999. Functional classification of harbor seal (Phoca vitulina) dives using depth profiles, swimming velocity, and an index of foraging success. Canadian Journal of Zoology 77, 74-87, doi: 10.1139/ cjz-77-1-74.

Lemieux Lefebvre S.L., Lesage V., Michaud R. \& Humphries M.M. 2018. Classifying and combining herd surface activities and individual dive profiles to identify summer behaviours of beluga (Delphinapterus leucas) from the St. Lawrence Estuary, Canada. Canadian Journal of Zoology 96, 393-410, doi: 10.1139/cjz-2017-0015.

Lowry L., Reeves R. \& Laidre K. 2017. Delphinapterus leucas. The IUCN Red List of Threatened Species 2017: T6335A50352346. Accessed on the internet at https://doi. org/10.2305/IUCN.UK.2017-3.RLTS.T6335A50352346.en on 13 November 2019.

Lowther A.D., Lydersen C., Fedak M.A., Lovell P. \& Kovacs K.M. 2015. The Argos-CLS Kalman filter: error structures and state-space modelling relative to Fastloc GPS data. PLoS One 10(4), e0124754, doi: 10.1371/journal.pone.0124754.

Lydersen C., Assmy P., Falk-Petersen S., Kohler J., Kovacs K.M., Reigstad M., Steen H., Strom H., Sundfjord A., Varpe O., Walczowski W., Weslawski J.M. \& Zajaczkowski M. 2014. The importance of tidewater glaciers for marine mammals and seabirds in Svalbard, Norway. Journal of Marine Systems 129, 452-471, doi: 10.1016/j.jmarsys.2013.09.006.

Lydersen C., Martin A.R., Kovacs K.M. \& Gjertz I. 2001. Summer and autumn movements of white whales Delphinapterus leucas in Svalbard, Norway. Marine Ecology Progress Series 219, 265-274, doi: 10.3354/meps2 19265.

Lydersen C., Nøst O.A., Lovell P., McConnell B.J., Gammelsrod T., Hunter C., Fedak M.A. \& Kovacs K.M. 2002. Salinity and temperature structure of a freezing Arctic fjord-monitored by white whales (Delphinapterus leucas). Geophysical Research Letters 29, article no. 2119, doi: 10.1029/2002GL015462.

Martin A.R., Hall P. \& Richard P.R. 2001. Dive behaviour of belugas (Delphinapterus leucas) in the shallow waters of western Hudson Bay. Arctic 54, 276-283, doi: 10.14430/ arctic787.

Martin A.R. \& Smith T.G. 1992. Deep diving in wild, free-ranging beluga whales, Delphinapterus leucas. Canadian Journal of Fisheries and Aquatic Sciences 49, 462-466, doi: 10.1139/f92-055.

Martin A.R. \& Smith T.G. 1999. Strategy and capability of wild belugas Delphinapterus leucas during deep, benthic diving. Canadian Journal of Zoology 77, 1783-1793, doi: 10.1139/ cjz-77-11-1783.

Martin A.R., Smith T.G. \& Cox O.P. 1993. Studying the behaviour and movements of High Arctic belugas with satellite telemetry. Symposia of the Zoological Society of London 66, 195-210.

Martin A.R., Smith T.G. \& Cox O.P. 1998. Dive form and function in belugas Delphinapterus leucas of the eastern Canadian High Arctic. Polar Biology 20, 218-228, doi: 10.1007/ s003000050299.

Moore S.E., Shelden K.E.W., Litzky L.K., Mahoney B.A. \& Rugh D.J. 2000. Beluga whale, Delphinapterus leucas, habitat associations in Cook Inlet, Alaska. Marine Fisheries Review 62, 60-80.

Mori Y. 1998. The optimal patch use in divers: optimal time budget and the number of dive cycles during bout. Journal of Theoretical Biology 190, 187-199, doi: 10.1006/ jtbi.1997.0550.

O'Corry-Crowe G. 2018. Beluga whale. In B. Würsig et al. (eds.): Encyclopedia of marine mammals. Pp. 93-96. New York: Academic Press.

R Development Core Team 2010. A language and environment for statistical computing. Vienna: R Foundation for Statistical Computing.

Reeves R.R., Ewins P.J., Agbayani S., Heide-Jørgensen M.P., Kovacs K.M., Lydersen C., Suydam R., Elliott W., Polet G., van Dijk Y. \& Blijleven R. 2014. Distribution of endemic cetaceans in relation to hydrocarbon development and commercial shipping in a warming Arctic. Marine Policy 44, 375-389, doi: 10.1016/j.marpol.2013.10.005.

Richard P.R., Heide-Jørgensen M.P. \& St Aubin D.J. 1998. Fall movements of belugas (Delphinapterus leucas) with satellite-linked transmitters in Lancaster Sound, Jones Sound, and northern Baffin Bay. Arctic 51, 5-16.

Richard P.R., Martin A.R. \& Orr J.R. 1997. Study of summer and fall movements and dive behavior of Beaufort Sea belugas, using satellite telemetry: 1992-1995. Environmental Studies Research Funds 134. Calgary: Environmental Studies Research Funds.

Richard P.R., Martin A. \& Orr J.R. 2001. Summer and autumn movements of belugas of the eastern Beaufort Sea stock. Arctic 54, 223-236.

Smith T.G. 1985. Polar bears, Ursus maritimus, as predators of belugas, Delphinapterus leucus. Canadian Field-Naturalist 99, 71-75.

Smith T.G. \& Martin A.R. 1994. Distribution of belugas, Delphinapterus leucas, in the Canadian High Arctic. Canadian Journal of Fisheries and Aquatic Sciences 51, 1653-1663, doi: 10.1139/f94-166.

Spielhagen R.F., Werner K., Sorensen S.A., Zamelczyk K., Kandiano E., Budeus G., Husum K., Marchitto T.M. \& Hald M. 2011 . Enhanced modern heat transfer to the Arctic by warm Atlantic water. Science 331, 450-453, doi: 10.1126/ science. 1197397.

Stirling I. 1997. The importance of polynyas, ice edges, and leads to marine mammals and birds. Journal of Marine Systems 10, 9-21, doi: 10.1016/S0924-7963(96)00054-1.

Thums M., Bradshaw C.J.A. \& Hindell M.A. 2008. A validated approach for supervised dive classification in diving vertebrates. Journal of Experimental Marine Biology and Ecology 363, 75-83, doi: 10.1016/j.jembe.2008. 06.024.

Tremblay Y., Robinson P.W. \& Costa D.P. 2009. A parsimonious approach to modeling animal movement data. PLoS One 4(3), e4711, doi: 10.1371/journal.pone. 0004711 .

Vacquié-Garcia J., Lydersen C., Ims R.A. \& Kovacs K.M. 2018. Habitats and movement patterns of white whales Delphinapterus leucas in Svalbard, Norway. Movement Ecology 6, article no. 21, doi: 10.1186/s40462-018-0139-z. 
Vihtakari M., Welcker J., Moe B., Chastel O., Tartu S., Hop H., Bech C., Descamps S. \& Gabrielsen G.W. 2018. Black-legged kittiwakes as messengers of Atlantification in the Arctic. Scientific Report 8, article no. 1178, doi: 10.1038/s41598-017-19118-8.

Watt C.A., Orr J. \& Ferguson S.H. 2016. A shift in foraging behaviour of beluga whales Delphinapterus leucas from the threatened Cumberland Sound population may reflect a changing Arctic food web. Endangered Species Research 31, 259-270, doi: 10.3354/esr00768.

Zuur A.F., Ieno E.N., Walker N.J., Saveliev A.A. \& Smith G.M. 2009. Mixed effects models and extensions in ecology with $R$. New York: Springer. 